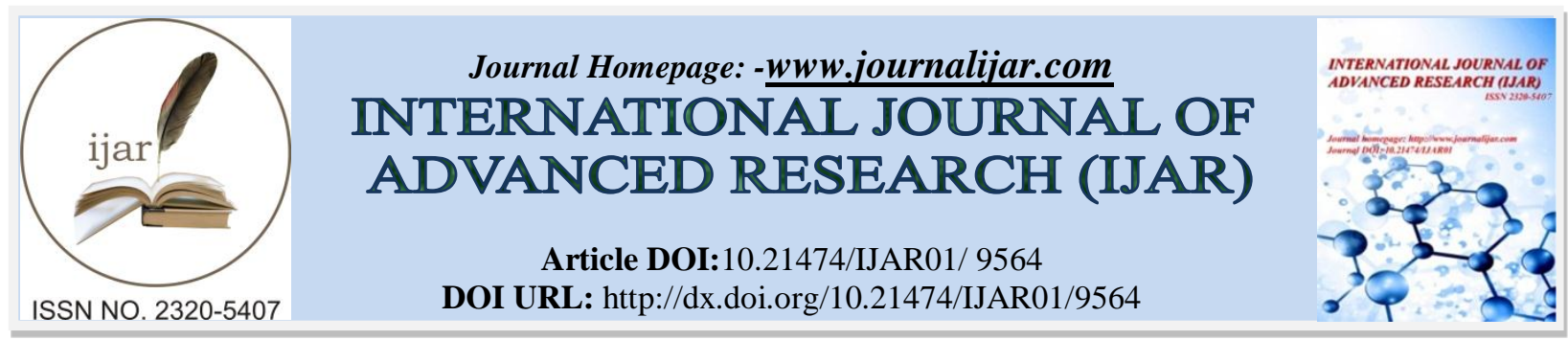

RESEARCH ARTICLE

\title{
EXTENT OF IMPLEMENTATION OF KINDERGARTEN PROGRAM AND ITS IMPACT ON SCHOOL READINESS YEAR-END ASSESSMENT (SReYA) IN THE ELEMENTARY SCHOOLS IN ONE DIVISION IN THE PHILIPPINES.
}

Melanie M. Cacao and Consorcia S. Tan.

Southville 6 Elementary School, Laguna State Polytechnic University.

\section{Manuscript Info}

Manuscript History

Received: 12 June 2019

Final Accepted: 14 July 2019

Published: August 2019

Key words:-

Kindergarten Program, School Readiness Year-End Assessment (SReYA), Blocks of Time, Classroom Area.

\section{Abstract}

This study aimed to determine the extent of implementation of kindergarten program and its impact on School Readiness Year-End Assessment (SReYA) in elementary schools in one division in the Philippines. The study was descriptive type of research, using a combination of self-constructed and adopted questionnaire, validated by the kindergarten division coordinator of the Department of Education and the researcher's adviser. The respondents of the study were the 134 kindergarten teachers in all the elementary schools in the division. The main concern of the study was kindergarten program implementation in terms of curriculum guide, blocks of time, classroom areas, instructional materials, methods of teaching and administrative support. Weighted mean, skewness, frequency counts, and percentage were utilized to analyze the data gathered. Chi-square and pearson $\mathrm{r}$ were employed to determine the significant relationship between the implementation of kindergarten program and SReYA results. Chi-square was also utilized to determine if there is a significant difference in the implementation of kindergarten program in terms of school type; big and small school, school location; east and west district school. The respondents were dominated by female teachers. The quarter percent of the total respondent continue earning education in master's program. Almost 50 percent has been teaching kindergarten for about 2-4 years. The standard class size of 21-30 pupils in the morning session were manifested, while 11-20 pupils can be seen in afternoon session. They were found to be highly knowledgeable in kindergarten curriculum guide and blocks of time. They were frequently utilizing the classroom areas, instructional materials and methods of teaching. Administrative support was found out to be highly observed by kindergarten teachers. The SReYA results from both east and west districts big and small schools were ready in terms of 10 domains. Findings revealed that there is a significant relationship 2 kindergarten programs and the 3 domains of SReYA such as fine motor skills and administrative support, numeracy skills and classroom areas, and sensory perceptive and classroom areas. Further, there is a significant difference in the curriculum guide as well as with administrator support over kindergarten program in big and small schools. 


\section{Introduction:-}

For so many years in the Philippines, preschool education is optional before entering the elementary level because not everyone can afford it. The Department of Social Welfare and Development (DSWD) is in charge of general planning and policy making, and promoting guidelines and standards to the local government units regarding early childhood education. However, recent events and activities show a high need for young children to undergo preschool education first before stepping into formal education.

Republic Act (RA) 8980 also known as the Early Childhood Care and Development or ECCD Act enacted in 2000 identifies the importance of providing preschool education and addressing young children's needs. It also recognizes parents as the children's primary caregivers and teachers.

ECCD in the Philippines provides for the needs and upholds the invisible rights of 6 year old children with the full range of holistic services for optimum growth and development. The most considerations of the law are health, nutrition safe and hygienic environment, psycho-social stimulation and cognitive development of a child.

The DepEd in accordance to Republic Act (RA) 10157 known as the Kindergarten Education Act, promotes equal opportunities for all five-year old children to avail of accessible mandatory and compulsory entry stage to basic education that effectively promote the holistic development of Filipino child. Thus, School Readiness Year-End Assessment of Kindergarten SReYA was restructured and conceptualized.

The implementation of Kindergarten Program sought that School Readiness Year-End Assessment of kindergarten (SReYA) as a tool to determine the achievement level of Kindergarten pupils across different developmental domains. Along with the implementation of this curriculum, SReYA was restructured and conceptualized into 10 domains. The SReYA cuts across the different developmental domains which are composed of performance and verbal/non-verbal test given individually and by groups, (Sec. 16.1.2. of Deped Order 32, s.2012).

Edgar Dale (1969) "Cone of Learning" believed that the child will have ninety percent (90\%) learning if the child "say and do" while at the teaching learning process. Learning by doing is an indication for assessment of learning, particularly authenticated and performance based which can be reflected in SReYA.

\section{Theoretical Framework}

Lev Vygotsky said that properly organized instruction will result in a child's intellectual development and bring about an entire series of other developmental processes, which might not be possible without instruction. Teachers need to provide experiences just beyond what children can do on their own but within what they can do with appropriate assistance (i.e. scaffolding). The zone of proximal development (ZPD) is the area between what children can do their own and what they can do with the assistance of an adult or a more developmentally advanced peer. According to Vygotsky (1978), child development is an active process whereby the child transforms socially shared process into internal constructs. Children are immersed in culture and society and thereby construct knowledge based on experiences within this context. (Facilitating Learning, a Metacognitive Process pg. 30-31)

Moreover, children come to school as active thinkers, possessing a natural curiosity and eagerness to learn. A major goal of education is to develop independent, creative and critical thinkers. Teachers support this development through capitalizing on children's natural desire to explore, manipulate and discover. Children who are engaged in a child-centered classroom develop problem-solving abilities which aid them in becoming competent and independent learners. The kindergarten classroom encourages children to think, to use their imagination and creative powers and to experience the joy of learning. Young children need to experience the world through their senses to maximize their learning capabilities.

One of related theory about children's readiness is the Constructivist theory. The theory suggests that children learn best by interacting with their environment, children are active participants in the advancement of their education and that the children themselves are often responsible for instigating their learning activities. Teachers following the Constructivist theory will focus more on providing an appropriate learning environment for the children then trying to establish whether a child is prepared or not. Teachers are to teach through concrete and simple concept first, 
helping the child to achieve mastery, and then move on to more abstract, difficult concepts as the child is ready, laying the foundation for future learning, (Introduction to Teach the Filipino Preschool, pg. 68-69).

The task of the constructivist teacher is to help students form their own questions and opinions and help them explore and interpret the results of their research. Constructivists see learning as a three-step process: discovery, concept introduction, and concept application. Lessons are structured around a question that "sparks their interest", to which the children form a hypothesis. Learning starts from basic concepts (whole picture) rather than around the details. Students construct their own meaning in a way that they best understand. The constructivist theory asks teachers to demonstrate an awareness of students' understanding by asking questions, listening to the answers and asking for elaboration. This is in contrast to the old traditional model of teaching which suggests that when learning for rote memory, there are right and wrong answers (winners and losers) and that it is better to be right, rather than to have interesting ideas. For learning to occur, there must be dialog and a match between the questions the children ask and what they are cognitively able to understand. Furthermore, authentic assessment used within the structure of constructivist theory, it promotes interdisciplinary inquiry which allows for broad and open-ended questions.

Likewise, Maria Montessori and John Dewey, supported the cognitive-development movement which is mirrored in a kindergarten pupil. Her work as a doctor and scientist set the stage for her theories on "planes of development" and "sensitive periods" in children. She also recognized the need for repetitive behavior (motor and mental) for cognitive development, as well as the importance the environment plays in stimulating children's mental growth and health. Like Dewey, Montessori stressed that experience is not just passive responses to stimuli (lessons). "In such a school the children, like butterflies mounted on pins, are fastened each to his place, the desk, spreading the useless wings of barren and meaningless knowledge which they have acquired" (Montessori, 1964, p. 14).

Based from the cited theories, children learn best through the guidance and help of the teacher or peer group and interaction with their environment thus, properly organized instruction will result in a child's intellectual development and bring out an entire series of other developmental processes. This is reflected to the kindergarten programs implemented in one division in the Philippines, while Montessori and Dewey pointed out that experience of kindergarten pupil is not just passive responses to stimuli (lessons) indeed, establishes itself in the child as a complex system of ideas actively constructed by the child himself during a series of physical processes representing an internal formation and physical growth as included in the 10 domains of SReYA.

The paradigm covers the independent and dependent variables. Independent variable presents Implementation of Kindergarten Program such as; Kindergarten Curriculum Guide, Blocks of Time, Classroom Areas, Method of Teaching, Instructional Materials and Administrative Support. The 10 domains of School Readiness Year-End Assessment (SReYA) including; Fine Motor, Gross Motor, Language Development, Cognitive and Intellectual Development, Numeracy, Sensory Perceptual, Social Environment, Physical Environment, Socio-Emotional Development, and Character and Values Development are under dependent variables.

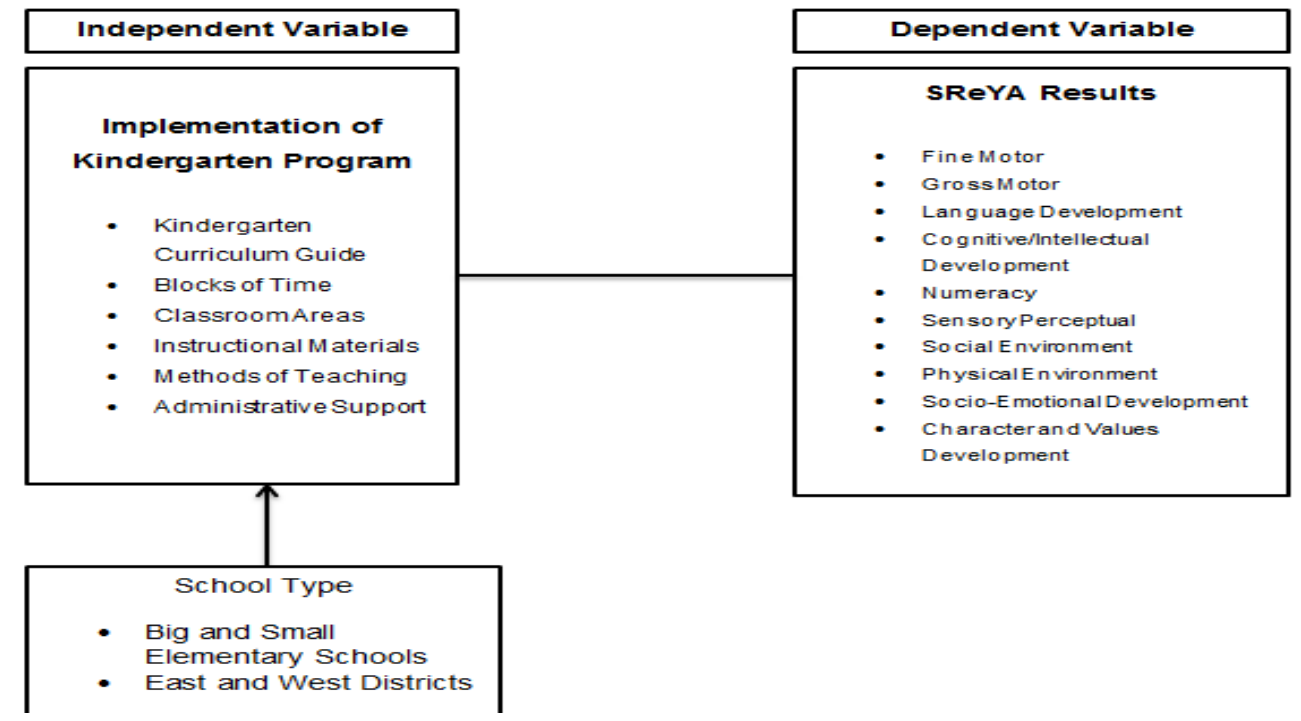

Figure 1:-Research Paradigm 
The researcher used data and correlation analysis to determine the relationship of the extent of implementation of kindergarten program and School Readiness Year-End Assessment (SReYA) and in the difference of implementation of kindergarten program in East and West Districts in the Division.

The researcher believed that the extent of implementation of kindergarten program in the Division can be reflected through the result of the 10 domains of SREYA. Thus, investigation about the implementation in big and small elementary schools in east and west district is the researcher's contribution to the new trend in educational system in education, inclusion of kindergarten in public schools stated in RA 10533 Enhanced Basic Education Act of 2013.

The study aimed to determine if there is a significant relationship between the implementation of kindergarten program and the SReYA results in Elementary Schools in the said division and if there is a significant difference between the implementation of kindergarten program in East and West Districts categorized into big and small elementary schools.

\section{Hypothesis}

The researcher posited the hypotheses stating that there is no significant relationship between the implementation of kindergarten program and the SReYA results and there is no significant difference between the implementation of kindergarten program in east and west districts categorized into big and small elementary schools.

\section{Methodology:- \\ Research Design}

The study was descriptive type of research, using a combination of self-constructed and adopted questionnaire, validated by the kindergarten division coordinator of the Department of Education and the researcher's adviser. The respondents of the study were the 134 kindergarten teachers in all the elementary schools in the division.

\section{Research Instrument}

The main instrument used in this study was a questionnaire adopted from the kindergarten curriculum guide (July 2015), DepEd Order 32, s 2012 Implementing Rules and Regulations of Republic Act (RA) No. 10157 also known as "Kindergarten Education Act”, DepEd Order 5, s. 2013 "Policy Guidelines on the Implementation of the School Readiness Year-End Assessment (SReYA) for Kindergarten and from the study of Guce, "Attitudes of Grade Schools and Kindergarten Teachers of Sta. Ana Elementary School Towards the New Kindergarten Curriculum" (March, 2012). The said instrument is used to determine the extent of implementation of kindergarten program and its impact on School Readiness Year-End Assessment (SReYA) 2015-2016.

The questionnaire is composed of three parts. The first part asked information regarding the demographic profile of the respondents in terms of school, cluster school, gender, educational attainment, length of teaching experience in kindergarten, and number of pupils per session. The second part consisted of kindergarten programs; curriculum guide, blocks of time, classroom areas, method of teaching, instructional materials and administrative support. The researcher used 5 point Likert Scale in determining the kindergarten teachers knowledge in terms of curriculum guide and blocks of time; where 5 means extremely knowledgeable, 4 is highly knowledgeable, 3 is knowledgeable, 2 is moderately knowledgeable and 1 is not knowledgeable. The same scale was used in terms of classroom areas, methods of teaching and instructional materials wherein; 5 means Always, 4 is Often, 3 is Sometimes, 2 is Seldom and 1 is Never. In terms of Administrative Support; 5 means Extremely Observed, 4 is Highly Observed, 3 is Observed, 2 is Moderately Observed and 1 is Not Observed. In addition, kindergarten programs such as method of teaching, instructional materials, and administrative support is adopted from Guce (2012). The last part consists of SReYA results from kindergarten through the 10 domains of SReYA as stipulated under Deped Order 32, s. 2012 and RA 10157.

The questionnaire was based on a pre-survey conducted among the peers of the researcher and anchored on the RA 10157 also known as "Kindergarten Education Act". After getting relevant information, the instrument is presented to the adviser for critique and suggestions. The questionnaire is content validated by the experts in the related fields using the institutional validation sheet. Their comments and suggestions were incorporated and the final draft of the instrument is approved for use by the adviser. Right after the consolidation, it was revised to suit the need of the study. 


\section{Data- Gathering Procedure}

The researcher first secured a permission to conduct survey from the Division Superintendent and from the Parent Supervisor of ten cluster schools in the concerned division. The principals of the responding schools involved in the study were also informed on the data gathering. The survey questionnaire was then distributed personally to the kindergarten teachers in their respective schools. Each respondent was carefully guided by the researcher. The date and time of the retrieval of the survey questionnaire was agreed upon by the researcher and the respondents. The results from the answered questionnaire were tabulated, analyzed, and interpreted.

\section{Statistical Treatment of the Data}

The researcher used the simple percentage in presenting the data gathered regarding the profile of the respondents. While in the assessment of the kindergarten teacher's knowledge in terms of curriculum guide and blocks of time, frequency of utilization of classroom areas, instructional materials and methods of teaching and observance of the administrator in the implementation of kindergarten program, the simple mean was used. In determining the School Readiness Year-End Assessment (SReYA) results of 56 elementary schools, the simple mean percentage was used. In terms of relationship among the assessment of kindergarten program and the results of 10 domains of SReYA in ten cluster schools, the Pearson Correlation was used. The difference between the implementation of kindergarten program to ten Domains of School Readiness Year-End Assessment (SReYA) was determined using the Chi-Square Test.

\section{Results And Discussion:-}

Seventy three or $54.5 \%$ of teacher-respondents who have $21-30$ pupils in afternoon class. 44 or $32.8 \%$ have above 31 pupils; 12 or $9 \%$ have $11-20$ pupils and the 3 or $2.2 \%$ of kindergarten teachers have less than 10 pupils in afternoon session, and $1.5 \%$ have no pupil to teach in afternoon session. It simply means that more than half of the total respondents have standard number size of pupils per session while 44 kindergarten teachers or $37.3 \%$ have oversized number of pupils per session.

The second objective determines the Kindergarten Teacher's Knowledge in the Implementation of Kindergarten Program in terms of kindergarten curriculum guide and blocks of time.

Table 1 shows the result in the Kindergarten revised curriculum guide dated July 2015. Cited are the lessons and the developmental domains that the kindergarten must learn and nurture. Further, the 10 developmental domains of SReYA including fine motor, gross motor, language development, cognitive/intellectual development, numeracy, sensory perceptual, social environment, physical environment, socio-emotional development and character and values development were reflected on the revised curriculum. It comprises 7 domains such as; Pagpapaunlad sa Kakayahang Emosyonal with 4.04 mean and 0.68 standard deviation, the result gathered was from the total mean percentage of its 4 sub-domains including, Pagpapahayag ng Sariling Emosyon, Pag-unawa sa Emosyon ng Iba, Pakikipag-ugnayan sa Kapwa at Nakatatanda and Pagpapahalaga sa Pagkakaiba which can be seen on the appendices.

Table 1:-Mean Assessment of the Teacher - Respondents Knowledge on the Implementation of Kindergarten Program in terms of Curriculum Guide

\begin{tabular}{|l|c|c|c|c|}
\hline Curriculum Guide & Mean & SD & Skewness & Verbal Description \\
\hline 1.Pagpapaunlad sa Kakayahang Emosyonal & 4.04 & 0.68 & -0.185 & HK \\
\hline 2.Pagpapaunlad sa Kakayahang Makapamuhay & 4.03 & 0.78 & -0.491 & HK \\
\hline 3.Kagandahang-Asal Pal Pagpapaunlad ng & 4.16 & 0.73 & -.371 & HK \\
\hline $\begin{array}{l}\text { 4.Kalusugang Pisikal at } \\
\text { Kakayahang Motor }\end{array}$ & & 0.71 & -0.246 & HK \\
\hline 5.Sining & 3.97 & 0.68 & -0.410 & HK \\
\hline 6. Understand Physical and Natural Environment & 4.00 & 0.70 & -0.160 & HK \\
\hline 7. Language, Literacy and Communication & 3.92 & 0.74 & -0.126 & HK \\
\hline \multicolumn{1}{|c|}{ Over all } & $\mathbf{4 . 0 0}$ & $\mathbf{0 . 7 2}$ & $\mathbf{- 0 . 2 4 8}$ & HK \\
\hline
\end{tabular}

Legend: (4.51 - 5.00) Extremely Knowledgeable (EK); ( $3.51-4.50)$ Highly Knowledgeable(HK); (2.513.50)Knowledgeable(K);(1.51 - 2.50) Moderately Knowledgeable(MK); (1.00 - 1.50) Not Knowledgeable (NK) 
Second domain was Pagpapaunlad sa Kakayahang Makapamuhay, which is composed of 3 sub-domains such as; Pakikisalamuha sa Iba pang Kasapi ng Pamilya, Pakikisalamuha sa Iba pang Kasapi ng Paaralan and Pakikisalamuha sa Iba pang Kasapi ng Komunidad, total mean result was 4.03 and 0.78 standard deviation. The third domain mentioned above was Kagandahang-Asal with 4.16 mean and 0.73 standard deviation. Kalusugang Pisikal at Pagpapaunlad ng Kakayahang Motor was the fourth domain with 4.06 mean and 0.71 standard deviation, it consist of 4 sub-domains such as Kasanayang Pisikal/Physical Fitness with, Kasanayang Gross Motor, Kasanayang Fine Motor, and Pangangalaga sa Sariling Kalusugan at Kaligtasan. The domain 5 was Sining including 7 sub-domains such as; Pagpapahalaga sa Kagandahan, Malikhaing Pagpapahayag, Sorting and Classifying, Counting, Number and Algebraic Thinking, Measurement and Data analysis and Probability. The sixth domain of the curriculum is Understand Physical and Natural Environment having the total mean of 4.00 and 0.70 standard deviation. It has 5 sub-domains including; Life Science focus was on Body Senses, Physical Science focus was on Properties and Change, Forces and Motion, Life Science and Earth Science focus was on Animals, Life Science was focus on Plants and Earth Science the focus was on Environment and the Weather. The last domain was Language, Literacy and Communication which comprises 11 sub-domains such as; Auditory Perception and Discrimination, Visual Perception and Discrimination, Oral Language, Phonological Awareness, Book and Print Awareness, Alphabet Knowledge, Study Skills, Composing, Attitude Toward Reading, Vocabulary Development and Listening Comprehension. It has the total mean percentage of 3.92 and 0.74 standard deviation.

Generally, table 1 shows that the overall mean for kindergarten curriculum guide is 4.00 which indicates "highly knowledgeable" with standard deviation of 0.72 . Most of the respondents respond positively as reflected in the -.246 skewness which means that kindergarten teacher chose higher score. Result reveals that thematic approach was not a hindrance to deliver the lessons also, school type and school location could not affect the accessibility on the new revised curriculum guide of kindergarten. Respondents are aware on the 7 developmental domains and its subdomains. It goes to show that kindergarten teachers are highly knowledgeable about the revised kindergarten curriculum guide and are updated.

Shown in table 2 are the kindergarten Blocks of Time. The Blocks of Time is popularly known for class program or schedule of kindergarteners. It comprises eight parts with different routines and activities which the teacher should provide such as; Arrival Time which consists of flag ceremony, prayer, and checking of attendance with 4.23 mean and -.497 skewness. Also, Meeting Time 1 where the teachers instruct about the activities in work period 1 and work period 2 with the mean of 4.22 and -.481 skewness conveying that respondents were highly knowledgeable. Meeting time 2 was the next block which means that pupils present their work; this block also showed that respondents were highly knowledgeable with 4.17 mean and -.406 skewness. Another block was rest or story telling with 4.19 mean and -.648 skewness, respondents were also highly knowledgeable. Work period 2 consists of small group activity with 4.15 and -.474 skewness while indoor and outdoor activity or recreational play has 4.07 mean and -.885 skewness. Last is meeting time 3 or the dismissal routine with 4.22 mean and -.326 skewness which means that kindergarten teachers were highly knowledgeable.

Table 2:-Mean Assessment of the Teacher - Respondents Knowledge on the of Implementation of Kindergarten Program in terms of Blocks of Time

\begin{tabular}{|c|c|c|c|c|c|}
\hline \multicolumn{2}{|c|}{ Indicators } & Mean & SD & Skewness & $\begin{array}{c}\text { Verbal } \\
\text { Decrintion }\end{array}$ \\
\hline B. & \multicolumn{5}{|l|}{ Blocks of Time } \\
\hline 1 & $\begin{array}{l}\text { Arrival Time (flag ceremony, prayer, } \\
\text { checking of attendance) }\end{array}$ & 4.23 & 0.71 & -.497 & HK \\
\hline 2 & $\begin{array}{l}\text { Meeting Time } 1 \text { (teacher instruction } \\
\text { about Work Period } 1 \& 2 \text { ) }\end{array}$ & 4.22 & 0.71 & -.481 & HK \\
\hline 3 & Work Period 1 (small group activity) & 4.16 & 0.78 & -.665 & HK \\
\hline 4 & $\begin{array}{l}\text { Meeting Time } 2 \text { (presentation of group } \\
\text { work) }\end{array}$ & 4.17 & 0.77 & -.406 & HK \\
\hline 5 & Rest/Story Telling & 4.19 & 0.75 & -.648 & HK \\
\hline 6 & Work Period 2 (small group activity) & 4.15 & 0.73 & -.474 & HK \\
\hline 7 & $\begin{array}{l}\text { Indoor/Outdoor Activity (recreational } \\
\text { play) }\end{array}$ & 4.07 & 0.82 & -.885 & HK \\
\hline 8 & Meeting Time 3 (Dismissal routine) & 4.22 & 0.69 & -.326 & HK \\
\hline
\end{tabular}




\begin{tabular}{|c|c|c|c|c|c|}
\hline & Over all & 4.18 & 0.75 & $-\mathbf{0 . 5 8 2}$ & HK \\
\hline
\end{tabular}

Legend: $(4.51-5.00)$ Extremely Knowledgeable (EK); ( $3.51-4.50)$ Highly Knowledgeable(HK); (2.513.50)Knowledgeable(K);(1.51 - 2.50) Moderately Knowledgeable(MK); (1.00 - 1.50) Not Knowledgeable (NK)

With the grand mean of 4.18 and 0.75 standard deviation and -0.582 skewness kindergarten teachers are "highly knowledgeable" in terms of kindergarten blocks of time. Most of the respondents answered higher scores as shown in -0.582 skewness.

Table 3 shows the assessment of kindergarten teachers on frequency of classroom utilization. Classroom areas should be utilized and are visible in the kindergarten classroom

Table 3:-Mean Assessment of the Teacher - Respondents on the Implementation of Kindergarten Program in terms of Classroom Utilization

\begin{tabular}{|c|c|c|c|c|}
\hline Classroom Areas & Mean & SD & Skewness & $\begin{array}{c}\text { Verbal } \\
\text { Description }\end{array}$ \\
\hline Reading Area & 3.98 & 0.75 & -.180 & Frequent \\
\hline Activity Area & 4.26 & 0.90 & -1.420 & Frequent \\
\hline Sleeping Area & 3.17 & 1.41 & -.245 & Frequent \\
\hline Washing Area & 4.25 & 0.88 & -1.447 & Frequent \\
\hline Playing Area & 4.37 & 0.76 & -1.162 & Frequent \\
\hline Over all & 4.01 & 1.06 & -1.158 & Frequent \\
\hline
\end{tabular}

Legend: $(4.51$ - 5.00) Always; (3.51 - 4.50) Frequent; (2.51 - 3.50) Sometimes; $(1.51$ - 2.50) Seldom; $(1.00$ 1.50) Never

The results inferred that kindergarten teachers "frequently utilized" the areas advised by the DepEd with the total mean of 4.01 with 1.06 standard deviation and -1.158 skewness. The result reveals that sleeping area has the least mean scores of 3.17, 1.41 standard deviation and -.245 skewness. Instructional materials include picture cards with 4.57 mean and -1.323 skewness, small books with 4.40 mean and -1.017 skewness, big books with 4.49 mean and 1.775 skewness, crayons with 4.69 mean and -1.912 skewness, popsicle sticks with 4.33 mean and -.828 skewness, plastic and wooden beads with 4.00 mean and -.941 skewness, painting kit with 4.25 mean and -.829 skewness, egg shells with 3.15 mean and -.209 skewness, mongo seeds with 3.42 mean and -.434 skewness and puppets and paper dolls with 3.85 mean and -.487 skewness.

Table 4:-Mean Assessment of the Teacher -Respondents on the Utilization of in terms of Instructional Materials

\begin{tabular}{|c|l|c|c|c|c|}
\hline \multicolumn{2}{|l|}{ Instructional Materials } & Mean & SD & Skewness & Verbal Description \\
\hline 1 & Picture cards & 4.57 & 0.62 & -1.323 & Always \\
\hline 2 & Small books & 4.40 & 0.71 & -1.017 & Frequent \\
\hline 3 & Big books & 4.49 & 0.73 & -1.775 & Frequent \\
\hline 4 & Crayons & 4.69 & 0.55 & -1.912 & Always \\
\hline 5 & Popsicle sticks & 4.33 & 0.71 & -.828 & Frequent \\
\hline 6 & Plastic and wooden beads & 4.00 & 0.86 & -.941 & Frequent \\
\hline 7 & Painting kit & 4.25 & 0.43 & -.829 & Frequent \\
\hline 8 & Egg shells & 3.15 & 1.17 & -.209 & Sometimes \\
\hline 9 & Monggo seeds & 3.42 & 1.13 & -.434 & Sometimes \\
\hline 10 & Puppets/paper dolls & 3.85 & 0.95 & -.487 & Frequent \\
\hline
\end{tabular}

Legend: (4.51 - 5.00) Always; (3.51 - 4.50) Frequent; (2.51 - 3.50) Sometimes; (1.51 - 2.50) Seldom; (1.00 1.50) Never 
Table 4 shows the kindergarten teacher's utilization on the ten enumerated instructional materials. As revealed by the results, kindergarten teachers "always" utilize the picture cards and crayons having means of 4.57 and 4.69 respectively.

However, eggshells and mongo seeds were "sometimes" used by the kindergarten teachers. Egg shells as instructional materials have mean of 3.15, 1.17 standard deviation and -.209 skewness, while mongo has 3.42 mean, However, table 4 clearly stated that the utilization of instructional materials was "frequently" used by the kindergarten teachers with the average mean of 4.11, 1.19 standard deviation and -1.98 skewness. Thus, Instructional materials played the most interesting part of child's process of learning. Most of the 5 year old children are fond of storytelling and reading through pictures, listening to stories delivered by the teacher and oral communication activities. The result is somewhat relative to the Progressive Education by Dewey (1859-1952). According to him children learn by doing through hands-on activities, projects, units of study, and child-centered integrated curriculum. This progressive movement emphasized how to think rather than what to think, with the curriculum like today's trend which focuses on scientific method of observing, experimenting and thinking divergently.

Shown in the table 5 is the mean assessment on the extent of implementation of kindergarten program in terms of method of teaching.

It is evident on the table 5 that the overall mean in the methods of teaching used by the kindergarten teachers is 4.33 described as "Frequent" with 0.78 standard deviation and -1.060 skewness. This affirmed that the six listed methods of teaching above are the method executed by the kindergarten teacher. It can be determine that the teaching learning process is not traditional nor teacher-centered but children-centered and inquiry-based.

Table 5:-Mean Assessment of the Teacher - Respondents on the Methods of TeachingUsed

\begin{tabular}{|c|l|c|c|c|c|}
\hline $\begin{array}{l}\text { Methods of } \\
\text { Teaching }\end{array}$ & Mean & SD & Skewness & $\begin{array}{c}\text { Verbal } \\
\text { Description }\end{array}$ \\
\hline 1 & $\begin{array}{l}\text { Story Telling } \\
\text { and Reading }\end{array}$ & 4.42 & 0.80 & -1.532 & Frequent \\
\hline 2 & $\begin{array}{l}\text { Listening } \\
\text { Story }\end{array}$ & 4.49 & 0.69 & -1.274 & Frequent \\
\hline 3 & $\begin{array}{l}\text { Oral } \\
\text { Communicatio } \\
\text { n Activities }\end{array}$ & 4.44 & 0.68 & -1.106 & Frequent \\
\hline 4 & $\begin{array}{l}\text { Interactive } \\
\text { Strategies }\end{array}$ & 4.37 & 0.79 & -1.031 & Frequent \\
\hline 5 & $\begin{array}{l}\text { Use of } \\
\text { Manipulative } \\
\text { Games }\end{array}$ & 4.25 & 0.81 & -1.000 & Frequent \\
\hline 6 & $\begin{array}{l}\text { Experiential } \\
\text { Small Group } \\
\text { Discussions }\end{array}$ & 4.02 & 0.84 & -.490 & Frequent \\
\hline
\end{tabular}

Legend: $(4.51-5.00)$ Always; $(3.51-4.50)$ Frequent; $(2.51-3.50)$ Sometimes; $(1.51-2.50)$ Seldom; $(1.00$ 1.50) Never

Thus, this is in agreement with Hamre, et. al., (2012) that, through animated delivery instruction the study participants show enthusiasm while delivering her instruction and delivers enjoyment of the learning process.

Fourth objective of the study is to investigate the level of observance of kindergarten teacher on the support of the administrator in the implementation of kindergarten program that was evident and seen in table 6.

Table 6 reveals the mean assessment of kindergarten teacher in terms of administrator support in the implementation of kindergarten program. It can be seen from the table above that the administrator support was "Highly Observed" 
by the kindergarten teachers; the result shows the overall mean of 3.82 with 0.83 standard deviation and -0.423 skewness. The result emphasized the importance of administrator support as mentioned earlier which the administrator considered the needs of the learner as stipulated in the School Improvement Plan (SIP) relative to RA

9155 Governance of Basic Education Act of 2001.

Table 6:-Mean Assessment of the Teacher - Respondents on the Administrator Support

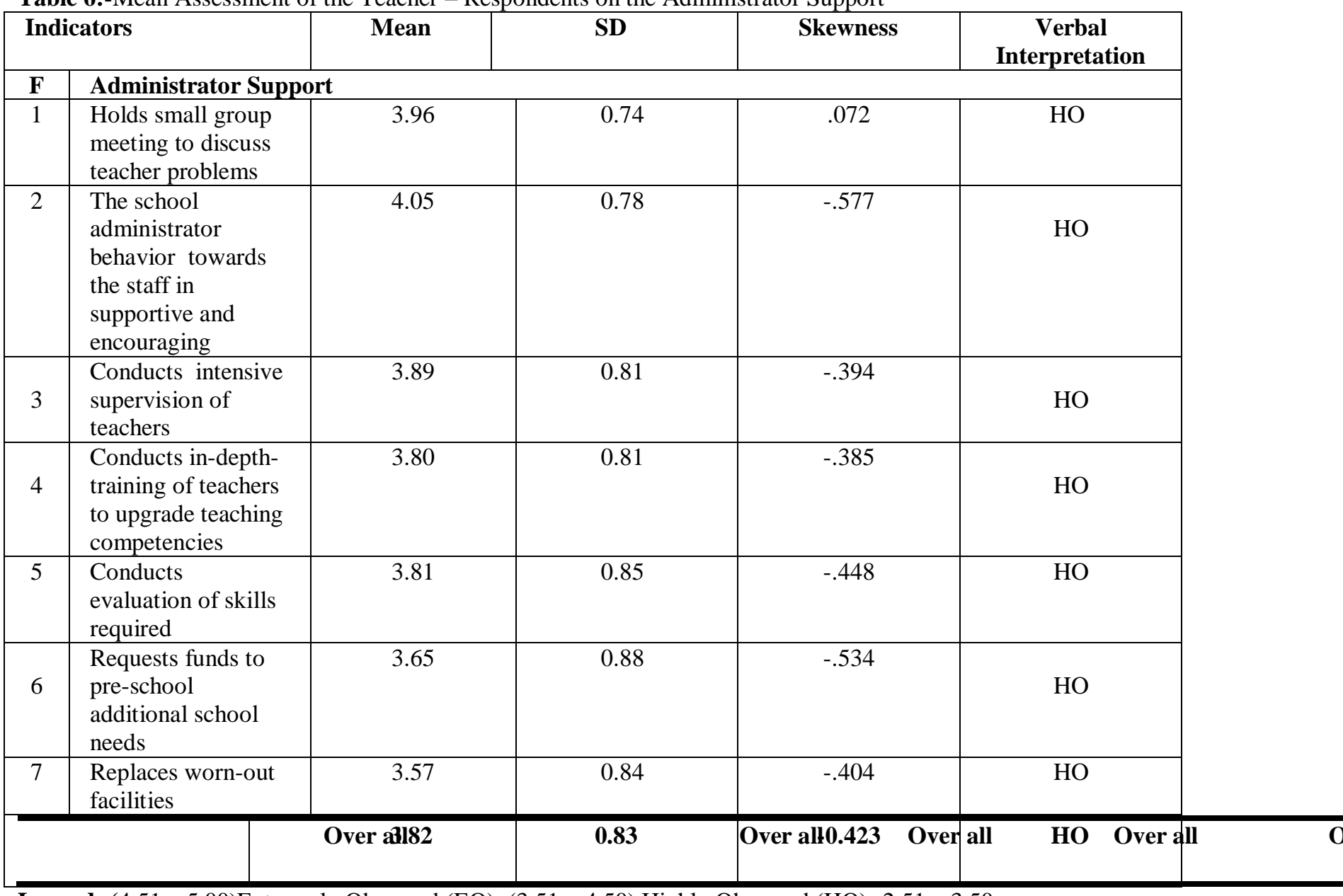

Legend: (4.51 - 5.00)Extremely Observed (EO); (3.51 - 4.50) Highly Observed (HO); $2.51-3.50$

Observed (O)(1.51 - 2.50) Moderately Observed (MO) (1.00 - 1.50) Not Observed (NO)

Thus, the goal of education is to provide a high-quality education for all students; it is not enough to provide them with capable well prepared teachers. They also need access to strong curriculum and materials with which to learn it, technology supports for learning and inquiry; reasonable class sizes, safe clean facilities and equitable opportunities to benefit from all of these, (Hammond and Bransford ,2005).

Table 7 presents the mean assessment of the extent of implementation of kindergarten program in terms of small school and big school.

Table 7:-Mean Assessment of the Extent of Implementation of Kindergarten Program in Small and Big Schools

\begin{tabular}{|l|c|c|c|c|c|c|}
\hline & \multicolumn{3}{|c|}{ Small School } & \multicolumn{3}{c|}{ Big School } \\
\hline Domains & Mean & SD & VD & Mean & SD & VD \\
\hline 1. Curriculum & 4.11 & 0.58 & HK & 3.96 & 0.58 & HK \\
\hline 2. Blocks of Time & 4.30 & 0.69 & HK & 4.13 & 0.68 & HK \\
\hline 3. Classroom Areas & 3.88 & 0.56 & F & 4.05 & 0.54 & $\mathrm{~F}$ \\
\hline 4. Instructional Materials & 4.05 & 0.46 & F & 4.04 & 0.69 & $\mathrm{~F}$ \\
\hline 5. Methods of Teaching & 4.37 & 0.54 & $\mathrm{~F}$ & 4.31 & 0.61 & $\mathrm{~F}$ \\
\hline
\end{tabular}




\begin{tabular}{|l|l|l|l|l|l|l|}
\hline 6. Administrator Support & 3.56 & 0.74 & HO & 3.92 & 0.66 & HO \\
\hline
\end{tabular}
Legend: (3.51 - 4.50) Highly Knowledgeable (HK), (3.51 - 4.50) Frequent (F), (3.51 - 4.50) Highly Observed (HO)

As seen in table 7, small and big schools was "highly knowledgeable" in terms of curriculum guide and blocks of time. Small school has 4.11 mean and 0.58 standard deviation greater results than big school with 3.96 mean and 0.58 standard deviation for the curriculum guide. Furthermore the 4.30 mean and 0.69 standard deviation result was from the small school, 4.13 mean and 0.68 standard deviation was from the domain of blocks of time in big school which seems that they were highly knowledgeable. In terms of utilization of classroom areas, it was revealed that kindergarten teachers in small and big school were "frequent" in utilizing different classroom areas with the mean percentage of 3.88 for small school and 4.05 in big school. The table also revealed that 0.56 standard deviation was result from small school and 0.54 in big school. This simply means that classroom areas in big school are adequate to the needs of the kindergarteners.

It was also revealed that small school and big school were "frequent" in utilizing instructional materials. Small school has 4.05 mean and 0.46 standard deviation while big school has 4.04 mean and 0.69 standard deviation. This result means that both types of school respond to the requisite in instructing the kindergarten pupils. In terms of methods of teaching used, the 4.37 mean and 0.54 standard deviation for small school and 4.31 mean and 0.61 standard deviation for big school revealed that teachers were "frequent" in using different methodologies in teaching kindergarten. Furthermore, teachers in small and big school "highly observed" the support of their administrator in the implementation of different programs of kindergarten.

Mean assessment of the extent of implementation of kindergarten program in terms of east and west school is presented in table 8 .

Table 8:-Mean Assessment of the Extent of Implementation of Kindergarten Program in East and West Schools

\begin{tabular}{|l|c|c|c|c|c|c|}
\hline & \multicolumn{3}{|c|}{ East School } & \multicolumn{4}{c|}{ West School } \\
\hline Domains & Mean & SD & VD & Mean & SD & VD \\
\hline 1. Curriculum & 4.2 & 0.52 & HK & 3.82 & 0.61 & HK \\
\hline 2. Blocks of Time & 4.23 & 0.61 & HK & 4.09 & 0.78 & HK \\
\hline 3. Classroom Areas & 4.05 & 0.48 & F & 3.94 & 0.63 & F \\
\hline 4. Instructional Materials & 4.04 & 0.57 & F & 4.13 & 0.51 & F \\
\hline 5. Methods of Teaching & 4.29 & 0.61 & F & 4.38 & 0.57 & F \\
\hline 6. Administrator Support & 3.94 & 0.53 & HO & 3.64 & 0.87 & HO \\
\hline
\end{tabular}

Legend: (3.51 - 4.50) Highly Knowledgeable (HK), (3.51 - 4.50) Frequent (F), (3.51 - 4.50) Highly Observed (HO)

Results revealed that east schools and west schools have almost the same result in terms of curriculum guide, blocks of time, classroom areas, instructional materials, methods of teaching and administrator support. Kindergarten teachers in east school; (4.20 mean), (0.52 SD) and west school; (3.82 mean), (0.61 SD) were "highly knowledgeable" in the revised curriculum guide for kindergarten. Also, they were "highly knowledgeable" in terms of blocks of time. For classroom areas, instructional materials and methods of teaching, both schools were "frequent" in utilizing each of the domains. The administrator support was "highly observed" by the respondents 1 with 3.94 mean and 0.53 standard deviation for east school and 3.64 mean and 0.87 standard deviation for west school.

Table 9 presents the mean assessment of the extent of implementation of kindergarten program in terms of curriculum guide.

Table 9:-Mean Assessment of the Extent of Implementation of Kindergarten Program in in terms of Curriculum Guide

\begin{tabular}{|l|c|c|c|c|c|c|}
\hline \multicolumn{9}{|c|}{ CURRICULUM GUIDE } \\
\hline & Big & VD & Mean & SD & VD \\
\hline East & Mean & SD & VD & 4.21 & 0.5 & HK \\
\hline
\end{tabular}




\begin{tabular}{|l|c|c|c|c|c|c|}
\hline West & 3.75 & 0.61 & HK & 3.96 & 0.58 & HK \\
\hline
\end{tabular}

Legend: $(3.51-4.50)$ Highly Knowledgeable (HK)

It shows that teachers in both schools were "highly knowledgeable" in terms of curriculum guide with 4.06 mean and 0.53 standard deviation in east big school and 3.75 mean and 0.61 standard deviation in west big school.

Shown in table 10 is the mean assessment of the extent of implementation of kindergarten program in terms of blocks of time.

Table 10:-Mean Assessment of the Extent of Implementation of Kindergarten Program in terms of Blocks of Time

\begin{tabular}{|c|c|c|c|c|c|c|}
\hline \multicolumn{7}{|c|}{ BLOCKS OF TIME } \\
\hline & \multicolumn{3}{|c|}{ Big } & \multicolumn{3}{|c|}{ Small } \\
\hline & Mean & SD & VD & Mean & SD & VD \\
\hline East & 4.18 & 0.53 & HK & 4.39 & 0.6 & HK \\
\hline West & 4.02 & 0.79 & HK & 4.22 & 0.78 & HK \\
\hline
\end{tabular}

Legend: (3.51 - 4.50) Highly Knowledgeable (HK)

Respondents were "highly knowledgeable" in terms of blocks of time. Big school in east district has 4.18 mean and 0.53 standard deviation while the 4.02 mean and 0.79 standard deviation was result of big school in west district.

This means that kindergarten teachers follow the daily routines of a kindergartener.

Table 11 presents the mean assessment of the extent of implementation of kindergarten program in terms of classroom areas.

Table 11:-Mean Assessment of the Extent of Implementation of Kindergarten Program in terms of Classroom Areas

\begin{tabular}{|c|c|c|c|c|c|c|}
\hline \multicolumn{7}{|c|}{ CLASSROOM AREAS } \\
\hline & \multicolumn{3}{|c|}{ Big } & \multicolumn{3}{|c|}{ Small } \\
\hline & Mean & SD & VD & Mean & SD & VD \\
\hline East & 4.06 & 0.46 & $\mathrm{~F}$ & 4.01 & 0.56 & F \\
\hline West & 4.05 & 0.65 & $\mathrm{~F}$ & 3.76 & 0.55 & $\bar{F}$ \\
\hline
\end{tabular}

Legend: (3.51 - 4.50) Highly Knowledgeable (HK)

The data implies that east and west big and small schools were "frequent" in utilizing different classroom areas. East big school has 4.06 mean and 0.46 standard deviation while the big school in west district has 4.05 mean and 0.65 standard deviation. This means that the ideal kindergarten classroom was frequently utilized and manifested in all big schools in the Division. In addition, small schools in both east and west district show that classroom areas were "frequently" utilized by teachers with mean percentage of 4.01 in east district and 0.56 standard deviation.

Table 12 illustrates the mean assessment of the extent of implementation of kindergarten program in terms of instructional materials. Results reveal that there was a frequent utilization of instructional materials in both east and west schools manifested in means of 4.16 and 4.10 respectively. Furthermore, small school in east district and west district shows that respondents are also "frequently" utilizing the instructional materials

Table 12:-Mean Assessment of the Extent of Implementation of Kindergarten Program in terms of Instructional Materials

\begin{tabular}{|l|c|c|c|c|c|c|}
\hline \multicolumn{7}{|c|}{ INSTRUCTIONAL MATERIALS } \\
\hline & \multicolumn{7}{|c|}{ Big } & Small & SD & VD \\
\hline & Mean & SD & VD & Mean & 0.54 & F \\
\hline East & 4.16 & 0.89 & F & 3.91 & 0.33 & F \\
\hline West & 4.10 & 0.59 & F & 4.18 & 0.33 \\
\hline
\end{tabular}

(3.51 - 4.50) Frequent (F)

as aid for instruction. The total mean of 3.19 and 0.54 standard deviation in east small school and 4.18 mean and 0.33 standard deviation in west district simply shows that kindergarten teacher had enough materials in teaching kindergarten. 
The mean assessment of the extent of implementation of kindergarten program in terms of methods of teaching is reflected in Table 13.

Table 13:-Mean Assessment of the Extent of Implementation of Kindergarten Program in terms of Methods of Teaching

\begin{tabular}{|c|c|c|c|c|c|c|}
\hline \multicolumn{7}{|c|}{ METHODS OF TEACHING } \\
\hline & \multicolumn{3}{|c|}{ Big } & \multicolumn{3}{|c|}{ Small } \\
\hline & Mean & SD & VD & Mean & SD & VD \\
\hline East & 4.28 & 0.59 & $\mathrm{~F}$ & 4.31 & 0.69 & $\mathrm{~F}$ \\
\hline West & 4.34 & 0.66 & $\mathrm{~F}$ & 4.44 & 0.36 & $\mathrm{~F}$ \\
\hline
\end{tabular}

$(3.51-4.50)$ Frequent $(\mathrm{F})$

It was revealed that both big and small school in east and west district were "frequently" utilizing the different methods in teaching kindergarten pupils.

Table 14 presents the mean assessment of the extent of implementation of kindergarten program in terms of administrator support. The data explained what type and location of the school has the least and maximum support for kindergarten. The table reveals that with 3.32 mean and 0.88 standard deviation, small the administrator support were "observed" in small school in west district. The east small school and big school in both district revealed that the administrator support was "highly observed" by

Table 14:-Mean Assessment of the Extent of Implementation of Kindergarten Program in terms of Administrator Support

\begin{tabular}{|l|c|c|c|c|c|c|}
\hline \multicolumn{9}{|c|}{ ADMINISTRATOR SUPPORT } \\
\hline & \multicolumn{3}{|c|}{ Sig } & \multicolumn{4}{c|}{ Small } \\
\hline & Mean & SD & VD & Mean & SD & VD \\
\hline East & 3.97 & 0.54 & HO & 3.8 & 0.54 & HO \\
\hline West & 3.82 & 0.82 & HO & 3.32 & 0.88 & O \\
\hline
\end{tabular}

Legend: (4.51 - 5.00)Extremely Observed (EO); (3.51 - 4.50) Highly Observed (HO); $2.51-3.50$

Observed $(\mathrm{O})$

$(1.51-2.50)$ Moderately Observed (MO) $(1.00-1.50)$ Not Observed (NO)

the kindergarten teachers with 3.8 mean score and 0.54 standard deviation in east small schools. Perhaps, big school in east district has the mean of 3.97 and 0.54 standard deviation while the big school in west district has mean score of 3.82 and 0.82 standard deviation. This implies that administrator in some small school in west district had minimum support in the implementation of kindergarten program.

The next objective of the study was to determine the results of School Readiness Year-End Assessment (SReYA) in the division. School Readiness Year-end Assessment is done to monitor learning, know where the child is at, and informs the child progress. It is crucial to identify child's developmental needs and does not determine academic achievement. The result of the assessment of a child shall be kept strictly confidential ratings and more qualitative/ descriptive and less numerical. This result will be the blueprint of grade one teacher so he/she can determine the potentials and best domains of his/her children the soonest, hence prepare the advance plans for the betterment of the pupils development..

Based from the table 15, the 26 schools in east district revealed that SReYA result was almost a hundred percent particularly in 10 domains; Fine Motor Skills, Gross Motor Skills, Language Development Skills, Cognitive/Intellectual Development, Numeracy, Sensory Perceptual, Social Environment, Physical Environment, Socio-Emotional Development, Character and Values Development.

As cited in table 15, School H scored $99.67 \%$ for Cognitive/Intellectual domain and $99.97 \%$ as overall performance for the assessment of SReYA. In addition, School M, got the total percentage of $96.8 \%$ in each SReYA domain and the overall percentage performance of the school. School R has $99.5 \%$ of the total SReYA performances with $99 \%$ of Fine and Gross Motor Skills, 98.5\% for Cognitive/Intellectual Skills and 98.3\% for Numeracy Skills. 
Table 15:-School Readiness Year-End Assessment (SReYA) results of Elementary Schools in East District in One Division in the Philippines

\begin{tabular}{|c|c|c|c|c|c|c|c|c|c|c|c|c|}
\hline & \multicolumn{10}{|c|}{ Domains } \\
\hline School & \multicolumn{10}{|c|}{ Percentage Pupils who are ready (\%) } \\
\hline A. & 100 & 100 & 100 & 100 & 100 & 100 & 100 & 100 & 100 & 100 & $\mathbf{1 0 0}$ \\
\hline B. & 100 & 100 & 100 & 100 & 100 & 100 & 100 & 100 & 100 & 100 & $\mathbf{1 0 0}$ \\
\hline C. & 100 & 100 & 100 & 100 & 100 & 100 & 100 & 100 & 100 & 100 & $\mathbf{1 0 0}$ \\
\hline D. & 100 & 100 & 100 & 100 & 100 & 100 & 100 & 100 & 100 & 100 & $\mathbf{1 0 0}$ \\
\hline E. & 100 & 100 & 100 & 100 & 100 & 100 & 100 & 100 & 100 & 100 & $\mathbf{1 0 0}$ \\
\hline F. & 100 & 100 & 100 & 100 & 100 & 100 & 100 & 100 & 100 & 100 & $\mathbf{1 0 0}$ \\
\hline G. & 100 & 100 & 100 & 100 & 100 & 100 & 100 & 100 & 100 & 100 & $\mathbf{1 0 0}$ \\
\hline H. & 100 & 100 & 100 & 99.67 & 100 & 100 & 100 & 100 & 100 & 100 & $\mathbf{9 9 . 9 7}$ \\
\hline I. & 100 & 100 & 100 & 100 & 100 & 100 & 100 & 100 & 100 & 100 & $\mathbf{1 0 0}$ \\
\hline J. & 100 & 100 & 100 & 100 & 100 & 100 & 100 & 100 & 100 & 100 & $\mathbf{1 0 0}$ \\
\hline K. & 100 & 100 & 100 & 100 & 100 & 100 & 100 & 100 & 100 & 100 & $\mathbf{1 0 0}$ \\
\hline L. & 100 & 100 & 100 & 100 & 100 & 100 & 100 & 100 & 100 & 100 & $\mathbf{1 0 0}$ \\
\hline M. & 96.8 & 96.8 & 96.8 & 96.8 & 96.8 & 96.8 & 96.8 & 96.8 & 96.8 & 96.8 & $\mathbf{9 6 . 8}$ \\
\hline N. & 100 & 100 & 100 & 100 & 100 & 100 & 100 & 100 & 100 & 100 & $\mathbf{1 0 0}$ \\
\hline O. & 100 & 100 & 100 & 100 & 100 & 100 & 100 & 100 & 100 & 100 & $\mathbf{1 0 0}$ \\
\hline P. & 100 & 100 & 100 & 100 & 100 & 100 & 100 & 100 & 100 & 100 & $\mathbf{1 0 0}$ \\
\hline Q. & 100 & 100 & 100 & 100 & 100 & 100 & 100 & 100 & 100 & 100 & $\mathbf{1 0 0}$ \\
\hline R. & 99 & 100 & 99 & 98.5 & 98.3 & 100 & 100 & 100 & 100 & 100 & $\mathbf{9 9 . 5}$ \\
\hline S. & 100 & 100 & 100 & 100 & 100 & 100 & 100 & 100 & 100 & 100 & $\mathbf{1 0 0}$ \\
\hline T. & 100 & 100 & 100 & 100 & 100 & 100 & 100 & 100 & 100 & 100 & $\mathbf{1 0 0}$ \\
\hline U. & 100 & 100 & 100 & 100 & 100 & 100 & 100 & 100 & 100 & 100 & $\mathbf{1 0 0}$ \\
\hline V. & 100 & 100 & 100 & 100 & 100 & 100 & 100 & 100 & 100 & 100 & $\mathbf{1 0 0}$ \\
\hline W. & 100 & 100 & 100 & 100 & 100 & 100 & 100 & 100 & 100 & 100 & $\mathbf{1 0 0}$ \\
\hline X. & 100 & 100 & 100 & 100 & 100 & 100 & 100 & 100 & 100 & 100 & $\mathbf{1 0 0}$ \\
\hline Y. & 100 & 100 & 100 & 100 & 100 & 100 & 100 & 100 & 100 & 100 & $\mathbf{1 0 0}$ \\
\hline Z. & 100 & 100 & 100 & 100 & 100 & 100 & 100 & 100 & 100 & 100 & $\mathbf{1 0 0}$ \\
\hline Overall & $\mathbf{9 9 . 8}$ & $\mathbf{9 9 . 9}$ & $\mathbf{9 9 . 8}$ & $\mathbf{9 9 . 8}$ & $\mathbf{9 9 . 8}$ & $\mathbf{9 9 . 9}$ & $\mathbf{9 9 . 9}$ & $\mathbf{9 9 . 9}$ & $\mathbf{9 9 . 9}$ & $\mathbf{9 9 . 9}$ & $\mathbf{9 9 . 9}$ \\
\hline & & & & & & & & &
\end{tabular}

Moreover, the 23 schools in east district scored $100 \%$ in the 10 domain of SReYA and its overall average performance.

Furthermore, the afore-mentioned results seem to have small differences as shown in the scores. It also assumes that kindergarteners were almost ready to be graders because most schools in east district were ready in each of the 10 domains of SReYA.

The total average performance score of 26 schools in east district is shown in table 15 . Included also are the 10 domains of SReYA with total average result such as; Fine Motor Skills 98.6\%, Gross Motor Skills 99\%, Language Development Skills 98\% Cognitive/ Intellectual Skills 96.9\%, Numeracy Skills 97\% Sensory/Perceptual Skills 98.1\%, Social Environment Skills 99\%, Physical Environment Skills 98.8\%, Socio-Emotional Development Skills 99.6\% and Character and Values Development 99\% with the total general average score of 99.9\%. This result simply means that east district performed better and responsible enough through the policies and challenges given by the new kindergarten program.

The result is supported by the study of Rodriguez (2010), that the roles of early childhood care and development teachers towards pupil's academic performance found that the pupil's performance is greatly influence by the teacher performance. Pupils learn under a teacher who is effectively and efficiently teaching. Also, she recommends that teacher development program is needed to enhance teaching competencies towards improved pupils performance.

\section{Presented in table 16 is the SReYA results of elementary schools in west district in the division.}


Table 16:-School Readiness Year-End Assessment (SReYA) results of Elementary Schools in West District in One Division in the Philippines

\begin{tabular}{|c|c|c|c|c|c|c|c|c|c|c|c|}
\hline & \multicolumn{10}{|c|}{ Domains } \\
\hline School & \multicolumn{10}{|c|}{ Percentage Pupils who are ready (\%) } \\
\hline A. & 100 & 100 & 100 & 100 & 100 & 100 & 100 & 100 & 100 & 100 & $\mathbf{1 0 0}$ \\
\hline B. & 100 & 100 & 100 & 100 & 100 & 100 & 100 & 100 & 100 & 100 & $\mathbf{1 0 0}$ \\
\hline C. & 96.9 & 96.9 & 96.9 & 95.4 & 95.4 & 100 & 100 & 100 & 100 & 98.5 & $\mathbf{9 8 . 5}$ \\
\hline D. & 100 & 100 & 100 & 100 & 100 & 100 & 100 & 100 & 100 & 100 & $\mathbf{1 0 0}$ \\
\hline E. & 100 & 100 & 100 & 100 & 100 & 100 & 100 & 100 & 100 & 100 & $\mathbf{1 0 0}$ \\
\hline F. & 100 & 100 & 100 & 100 & 100 & 100 & 100 & 100 & 100 & 100 & $\mathbf{1 0 0}$ \\
\hline G. & 100 & 100 & 100 & 100 & 100 & 100 & 100 & 100 & 100 & 100 & $\mathbf{1 0 0}$ \\
\hline H. & 100 & 100 & 100 & 100 & 100 & 100 & 100 & 100 & 100 & 100 & $\mathbf{1 0 0}$ \\
\hline I. & 100 & 100 & 100 & 100 & 100 & 100 & 100 & 100 & 100 & 100 & $\mathbf{1 0 0}$ \\
\hline J. & 100 & 98.4 & 87.1 & 72.6 & 56.5 & 66.1 & 95.2 & 81.2 & 96.8 & 95.2 & $\mathbf{8 4 . 9}$ \\
\hline K. & 100 & 100 & 100 & 100 & 100 & 100 & 100 & 100 & 100 & 100 & $\mathbf{1 0 0}$ \\
\hline L. & 100 & 100 & 100 & 100 & 100 & 100 & 100 & 100 & 100 & 100 & $\mathbf{1 0 0}$ \\
\hline M. & 100 & 100 & 100 & 100 & 100 & 100 & 100 & 100 & 100 & 100 & $\mathbf{1 0 0}$ \\
\hline N. & 95.3 & 96.1 & 96.1 & 91.4 & 93 & 96.1 & 94.5 & 96.1 & 96.1 & 96.1 & $\mathbf{9 5 . 1}$ \\
\hline O. & 100 & 100 & 100 & 100 & 100 & 100 & 100 & 100 & 100 & 100 & $\mathbf{1 0 0}$ \\
\hline P. & 100 & 100 & 100 & 100 & 100 & 100 & 100 & 100 & 100 & 100 & $\mathbf{1 0 0}$ \\
\hline Q. & 100 & 100 & 100 & 100 & 100 & 100 & 100 & 100 & 100 & 100 & $\mathbf{1 0 0}$ \\
\hline R. & 97.3 & 100 & 100 & 96.2 & 95.4 & 93.8 & 100 & 100 & 100 & 100 & $\mathbf{9 8 . 3}$ \\
\hline S. & 100 & 100 & 99.5 & 92.4 & 94 & 100 & 97.8 & 95.1 & 99.5 & 100 & $\mathbf{9 7 . 8}$ \\
\hline T. & 100 & 100 & 100 & 100 & 100 & 100 & 100 & 100 & 100 & 100 & $\mathbf{1 0 0}$ \\
\hline U. & 100 & 100 & 100 & 100 & 100 & 100 & 100 & 100 & 100 & 100 & $\mathbf{1 0 0}$ \\
\hline V. & 99 & 100 & 99 & 98.3 & 100 & 100 & 100 & 100 & 100 & 100 & $\mathbf{9 6 . 6}$ \\
\hline W. & 77.5 & 85 & 86.7 & 86.7 & 100 & 100 & 100 & 100 & 100 & 100 & $\mathbf{9 3 . 6}$ \\
\hline X. & 98.4 & 98.4 & 95.1 & 89.5 & 97.7 & 96.4 & 95.7 & 96.4 & 97 & 96.4 & $\mathbf{9 6 . 1}$ \\
\hline Y. & 100 & 100 & 100 & 100 & 100 & 100 & 100 & 100 & 100 & 100 & $\mathbf{1 0 0}$ \\
\hline Overall & $\mathbf{9 8 . 6}$ & $\mathbf{9 9}$ & $\mathbf{9 8}$ & $\mathbf{9 6 . 9}$ & $\mathbf{9 7}$ & $\mathbf{9 8 . 1}$ & $\mathbf{9 9}$ & $\mathbf{9 8 . 8}$ & $\mathbf{9 9 . 6}$ & $\mathbf{9 9}$ & $\mathbf{9 8 . 4}$ \\
\hline & & & & & & & & & & & \\
\hline
\end{tabular}

West district is comprised of 25 schools considered as rural area where there is difficulty in the accessibility of the materials such as picture cards, small books, big books, crayons, popsicle sticks, plastic and wooden beads, painting kit, egg shells, mongo seeds puppet and paper dolls . Out of these schools, 7 elementary schools have varied scores in terms of 10 developmental domains of SReYA and 18 elementary schools have a hundred percent scores in the same assessment.

Furthermore, findings revealed the general average score of 10 developmental domains such as; Fine Motor Skills 98.6, Gross Motor Skills 99\%, Language Development Skills 98\%, Cognitive/Intellectual Skills 96.9\%, Numeracy Skills 97\%, Sensory-Perceptual Skills 98.1\%, Social Environment 99\%, Physical Environment 98.8\%, SocioEmotional Development (99.6\%) and Character and Values Development 99\%. It was seen from the above table that the west district school was $98.4 \%$ ready in terms of 10 developmental domains of School Readiness Year-End Assessment. The researcher analyzed the findings of the relationship of kindergarten program and the ten domains of SReYA results.

Table 17 presents the test of significant relationship between implementation of kindergarten program and the SReYA results in terms of Fine Motor Skills.

Table 17:-Test of Significant Relationship between Implementation of Kindergarten Program and the SReYA results in terms of Fine Motor Skills

\begin{tabular}{|l|c|c|}
\hline Pairs of Variables & $\boldsymbol{r}$-value & $\boldsymbol{p}$-value \\
\hline Curriculum Guide and Fine Motor Skills & -.037 & .670 \\
\hline Blocks of Time and Fine Motor Skills & -.032 & .712 \\
\hline Classroom Areas and Fine Motor Skills & -.034 & .782 \\
\hline
\end{tabular}




\begin{tabular}{|l|c|c|}
\hline Instructional Materials and Fine Motor Skills & .112 & .198 \\
\hline Methods of Teaching and Fine Motor Skills & -.129 & .138 \\
\hline Administrator Support and Fine Motor Skills & -.191 & .027 \\
\hline
\end{tabular}

Significant at $\mathbf{0 5}$ level of significance

Based on the findings Administrator Support and Fine Motor Skills have "significant" relationship which seems to be very evident where respondents answered positively as discussed in the previous data. Furthermore, Curriculum Guide and Fine Motor Skills have weighted -.037 r-value and .670 p-value which means "Not Significant", Blocks of Time and Fine Motor Skills have -.032 r-value and $.712 \mathrm{p}$-value that seems to have the relationship of "Not Significant". Also, Fine Motor Skills and its relationship between Classroom Areas; -.034 r-value, .782 p-value, Instructional Materials; .112 r-value, .198 p-value and Methods of Teaching; -.129 r-value and $.138 \mathrm{p}$-value seems to be not significant in Fine Motor Skills. The result was supported by Gawat (2015), there is no significant relationship between the level of readiness of pupils on SReYA in terms of cognitive,motor and physical health and well-being and the teacher factors.

Table 18 shows the test of significant relationship between the implementation of Kindergarten Program and the SReYA results in terms of Gross Motor Skills.

Table 18:-Test of Significant Relationship between Implementation of Kindergarten Program and the SReYA results in terms of Gross Motor Skills

\begin{tabular}{|l|c|c|}
\hline Pairs of Variables & $\boldsymbol{r}-$ value & $\boldsymbol{p}$ - value \\
\hline Curriculum Guide and Gross Motor Skills & -0.70 & .425 \\
\hline Blocks of Time and Gross Motor Skills & -.061 & .483 \\
\hline Classroom Areas and Gross Motor Skills & -.020 & .821 \\
\hline Instructional Materials and Gross Motor Skills & .135 & .120 \\
\hline Methods of Teaching and Gross Motor Skills & -.117 & .178 \\
\hline Administrator Support and Gross Motor Skills & -.155 & .074 \\
\hline
\end{tabular}

Significant at $\mathbf{. 0 5}$ level of significance

The kindergarten program such as Curriculum Guide and Gross Motor Skills with -0.70 weighted r-value and .425 p-value, Blocks of Time and Gross Motor Skills having -.061 r-value and .483 p-value, Classroom Areas and Gross Motor Skills has -.020 and .821 p-value, Instructional Materials and Gross Motor Skills with .135 r-value, .120 pvalue, and Administrator Support and Gross Motor Skills has "No Significant" relationship with the r-value of -..155 and $.074 \mathrm{p}$-value. This goes to show that there is no significant relationship between the kindergarten program and Gross Motor Skills.

Shown in table 19 is the test of significant relationship between implementation of kindergarten program and SReYA results in terms of Language Development Skills.

Table 19:-Test of Significant Relationship between Implementation of Kindergarten Program and the SReYA results in terms of Language Development Skills

\begin{tabular}{|c|c|c|}
\hline Pairs of Variables & $r$-value & $p$ - value \\
\hline Curriculum Guide and Language Development Skills & -.007 & 940 \\
\hline Blocks of Time and Language Development Skills & .025 & .772 \\
\hline Classroom Areas and Language Development Skills & -.017 & 843 \\
\hline Instructional Materials and Language Develoment Skills & .062 & 477 \\
\hline Methods of Teaching and Language Develoment Skills & -.160 & .065 \\
\hline Administrator Support and Language Develoment Skills & -.102 & 241 \\
\hline
\end{tabular}

Significant at .05 level of significance

Analysis showed that there is "no significant" relationship among the kindergarten program and language development skills since p-value ranges from .065 to .940 which signifies that greater than the .05 level of significance. The result was supported by Blake (2006) cited by Bautista (2013) According to the study, pre-the child develops wholesome behavior towards others and he acquires correct speech habits and desirable patterns as he shares experiences. A child who comes from a naturally deprived home has opportunity to enrich his experiential background through permissive and stimulating environment in pre-school classes. 
The test of significant relationship between implementation of kindergarten Program and the SReYA results in terms of cognitive intellectual skills is presented in the next table.

Table 20:-Test of significant relationship between implementation of Kindergarten Program and the SReYA results in terms of Cognitive Intellectual Skills

\begin{tabular}{|l|c|c|}
\hline Pairs of Variables & $\boldsymbol{r}-$ value & $\boldsymbol{p}-$ value \\
\hline Curriculum Guide and Cognitive Intellectual Skills & .006 & .942 \\
\hline Blocks of Time and Cognitive Intellectual Skills & .076 & .382 \\
\hline Classroom Areas and Cognitive Intellectual Skills & -.017 & .849 \\
\hline Instructional Materials Cognitive Intellectual Skills & .007 & .938 \\
\hline Methods of Teaching and Cognitive Intellectual Skills & -165 & .057 \\
\hline Administrator Support and Cognitive Intellectual Skills & -.062 & .479 \\
\hline
\end{tabular}

Significant at .05 level of significance

The results revealed that there is "no significant" relationship between the Cognitive Skills and kindergarten program; Curriculum Guide, Blocks of Time, Classroom Areas, Instructional Materials, Methods of Teaching and Administrator Support with p-values that range from .057 to .849 are greater than the level of significance of 0.05 . This signifies that the Kindergarten Program does not affect the total performance of SReYA in terms of Cognitive Intellectual Skills.

The analysis in the relationship between implementation of kindergarten program and the SReYA results in terms of Numeracy Skills is illustrated in Table 21. The result was related to the study of Oliver et., al (2011), which revealed that teacher's classroom management practices have a significant positive effect on decreasing problem behavior in the classroom.

Table 21:-Test of significant relationship between implementation of Kindergarten Program and the SReYA results in terms of Numeracy Skills

\begin{tabular}{|l|c|c|}
\hline Pairs of Variables & $\boldsymbol{r}-$ value & $\boldsymbol{p}-$ value \\
\hline Curriculum Guide and Numeracy Skills & .022 & .799 \\
\hline Blocks of Time and Numeracy Skills & .086 & .325 \\
\hline Classroom Areas and Numeracy Skills & .222 & .010 \\
\hline Instructional Materials and Numeracy Skills & .063 & .469 \\
\hline Methods of Teaching and Numeracy Skills & -.057 & .509 \\
\hline Administrator Support and Numeracy Skills & .036 & .676 \\
\hline
\end{tabular}

\section{Significant at $\mathbf{0 5}$ level of significance}

It can be seen in table 21 that the p-value in Classroom Areas and Numeracy Skills is .010 which is significant at 0.05 significance level. Thus, there is a significant relationship between the mean percentage of SReYA results in terms of Numeracy Skills and Kindergarten Program in terms of classroom areas.. Nevertheless, the kindergarten program like Curriculum Guide .799, Blocks of Time .325, Instructional Materials .469, Methods of Teaching .509 and Administrator Support .676, the p-values are greater than the 0.05 level of significance emphasizing no significant relationship between the Numeracy Skills results and the Kindergarten Program.

Table 22 revealed that there is a "significant" relationship between Classroom Areas and Sensory-Perceptive Skills with $.213 \mathrm{r}$-value and $.013 \mathrm{p}$-values less than the.05 level of significance.

Table 22:-Test of Significant Relationship between Implementation of Kindergarten Program and the SReYA Results in terms of Sensory Perceptive Skills

\begin{tabular}{|l|c|c|}
\hline Pairs of Variables & $\boldsymbol{r}-$ value & $\boldsymbol{p}-$ value \\
\hline Curriculum Guide and Sensory Perceptive Skills & .054 & .538 \\
\hline Blocks of Time and Sensory Perceptive Skills & .099 & .253 \\
\hline Classroom Areas and Sensory Perceptive Skills & .213 & .013 \\
\hline Instructional Materials and Sensory Perceptive Skills & .079 & .365 \\
\hline Methods of Teaching and Sensory Perceptive Skills & -.066 & .447 \\
\hline
\end{tabular}


Moreover, most of the p-values are greater than significance level which ranges from .253 to .789. Therefore there is no significant relationship between the mean percentage results of Sensory-Perceptive Skills and the implementation of kindergarten program was observed. This is supported by Hammond (2006), having teacher preparation programs that include core knowledge are important but teachers also need to be prepared to recognize students diverse ways of learning and develop the ability to continually adapt their teaching to effectively respond to the multifaceted nature of the classroom.

Table 23 shows that there is "no significant" relationship between all kindergarten program and Social Environment Skills. This means that all the p-values range from .179 to .913 is greater than the 0.05 level of significance which indicates that there is no significant relationship. This is somehow reflected in the study of Ladd, et., al. (2006), who emphasized the importance of personal and social skills and the impact the students' social behaviors, relationships with peers and relationships with teachers have on their school adjustment.

Table 23:-Test of significant relationship between implementation of Kindergarten Program and the SReYA results in terms of Social Environment Skills

\begin{tabular}{|l|c|c|}
\hline Pairs of Variables & $\boldsymbol{r}$-value & $\boldsymbol{p}$-value \\
\hline Curriculum Guide and Social Environment Skills & .026 & .768 \\
\hline Blocks of Time and Social Environment Skills & .082 & .348 \\
\hline Classroom Areas and Social Environment Skills & -.033 & .706 \\
\hline Instructional Materials Social Environment Skills & -.010 & .913 \\
\hline Methods of Teaching and Social Environment Skills & -.117 & .179 \\
\hline Administrator Support and Social Environment Skills & -.031 & .726 \\
\hline
\end{tabular}

The analysis in the relationship between the implementation of kindergarten program and the SReYA results in terms of Physical Environment Skills is reflected in Table 24.

Table 24:-Test of significant relationship between implementation of Kindergarten Program and the SReYA results in terms of Physical Environment Skills

\begin{tabular}{|c|c|c|}
\hline Pairs of Variables & $r$-value & $p$-value \\
\hline Curriculum Guide and Physical Environment Skills & .014 & .874 \\
\hline Blocks of Time and Physical Environment Skills & .090 & 298 \\
\hline Classroom Areas and Physical Environment Skills & .095 & .275 \\
\hline Instructional Materials and Physical Environment Skills & .020 & .822 \\
\hline Methods of Teaching and Physical Environment Skills & -.093 & 286 \\
\hline Administrator Support and Physical Environment Skills & .014 & .875 \\
\hline
\end{tabular}

No significant relationship was found between the implementation of kindergarten program and the SReYA results in terms of Physical Environment. The p-values ranges from .275 to .875 , this means that all the p-values are greater than the level of significance. This is somewhat related to the study of Hamre, et. al., (2012) which stated that the child's intellectual functioning at school is directly related to the quality of the social relationship developed in the classroom environment. The support for including the essential building a sense of community in the classroom and sense of partnership of classroom comes from each student becoming a significant part of official learning environment.

Exhibited in Table 25, is the analysis in the relationship between implementation of kindergarten program and the SReYA results in terms of Socio-Emotional Development Skills. It shows that there is "no significant" relationship between all kindergarten program and Socio-Emotional Development Skills.

Table 25:-Test of significant relationship between implementation of Kindergarten Program and the SReYA results in terms of Socio-Emotional Development Skills

\begin{tabular}{|l|c|c|}
\hline Pairs of Variables & $\boldsymbol{r}$ - value & $\boldsymbol{p}$ - value \\
\hline Curriculum Guide and Socio-Emotional Development Skills & .046 & .599 \\
\hline
\end{tabular}




\begin{tabular}{|c|c|c|}
\hline Blocks of Time and Socio-Emotional Development Skills & .087 & .318 \\
\hline Classroom Areas and Socio-Emotional Development Skills & -.010 & .912 \\
\hline Instructional Materials and Socio-Emotional Development Skills & .017 & .842 \\
\hline Methods of Teaching and Socio-Emotional Development Skills & -.100 & .252 \\
\hline Administrator Support and Socio-Emotional Development Skills & -.038 & .663 \\
\hline
\end{tabular}

It also shown in the table that all p-values range from .252 to .912 is greater than the 0.05 level of significance which indicates that there is no significant relationship. This result is connected to the study of Blake (2006) cited by Bautista (2013) that contends that the child's experiences outside home have the great influence on the child's personality. The child develops wholesome behavior towards other and he acquires correct speech habits and desirable patterns as he shares experiences.

The analysis in the relationship between implementation of kindergarten program and the SReYA results in terms of Character and Values Development is presented in table 26. The results revealed that there is "no significant" relationship between the implementation of kindergarten program and the SReYA results in terms of Character Development. The p-values of .242 to .930 indicate that these are greater than the 0.05 level of significance. Therefore, there is no significant relationship among implementation of kindergarten program and the Character and Values Development results. This result is somehow related to the above-mentioned study by Blake (2006) cited by Bautista (2013) that the child's experiences outside the home have great influence in the child's personality.

Table 26:-Test of significant relationship between implementation of Kindergarten Program and the SReYA results in terms of Character and Values Development Skills

\begin{tabular}{|c|c|c|}
\hline Pairs of Variables & $r$-value & $p$-value \\
\hline Curriculum Guide and Character and Values Development & .045 & 606 \\
\hline Blocks of Time and Character and Values Development & .074 & .395 \\
\hline Classroom Areas and Character and Values Development & -.068 & .930 \\
\hline Instructional Materials and Character and Values Development & .019 & .831 \\
\hline Methods of Teaching and Character and Values Development & -.102 & .242 \\
\hline Administrator Support and Character and Values Development & -.018 & .840 \\
\hline
\end{tabular}

The findings in the test of significant difference between the implementation of kindergarten program in East and West Districts in table 27 revealed that there is "no significant" difference in four program of kindergarten implementation such as; Blocks of Time .233 p-value, Classroom Areas .286 p-value, Instructional Materials .846 pvalue and methods of teaching $.405 \mathrm{p}$-value. It means that the enumerated p-values are greater than 0.05 level of significance. However, Curriculum Guide with p-value of .003 and Administrator Support .017 indicates that it is less than the level of significance. This means that the curriculum guide and administrator support can affect the

Table 27:-Test of Significant Difference between the Implementation of Kindergarten Program in East and West Districts

\begin{tabular}{|l|c|c|}
\hline Kindergarten Program & $\boldsymbol{t}$ - value & $\boldsymbol{p}$ - value \\
\hline Curriculum Guide & 3.017 & .003 \\
\hline Blocks of Time & 1.197 & .233 \\
\hline Classroom Areas & 1.072 & .286 \\
\hline Instructional Materials & -.194 & .846 \\
\hline Methods of Teaching & -.836 & .405 \\
\hline Administrator Support & 2.418 & .017 \\
\hline
\end{tabular}

implementation of kindergarten program by holding small group meeting to discuss teacher problems, his or her behavior towards the staff, monitoring and conducting intensive supervision to teachers encouraging his or her teacher to attend or he himself conducts an in-depth training to upgrade teaching competencies, conducting evaluation of the skills required request funds to pre-school additional needs and administrator replaces worn-out facilities of kindergarten. 
Table 28 revealed that most of the implementation of kindergarten program is not significantly different among big and small schools. Based on the findings, there is "no significant" difference in most kindergarten program.

Table 28:-Test of Significant Difference between the Implementation of Kindergarten Program in Big and Small Schools

\begin{tabular}{|l|c|c|}
\hline Kindergarten Program & $\boldsymbol{t}$ - value & $\boldsymbol{p}$ - value \\
\hline Curriculum Guide & -1.356 & .177 \\
\hline Blocks of Time & -1.302 & .195 \\
\hline Classroom Areas & 1.645 & .102 \\
\hline Instructional Materials & .659 & .511 \\
\hline Methods of Teaching & -.595 & .553 \\
\hline Administrator Support & 2.737 & .007 \\
\hline
\end{tabular}

Specifically, in terms of implementation of Curriculum Guide 1.77, Blocks of Time .195, Classroom Areas .102, Instructional Materials .511, and Methods of Teaching .553. However, Administrator Support is "significantly different" with .007 p-values less than the level of significance. The result is somewhat relative to Berhman, et., al (2005) evaluated the importance of Early Childhood Development (ECD) initiative of the Philippine government using Longitudinal data collected over three years.

\section{Conclusions:-}

The study concludes no significant relationship between the implementation of kindergarten program and the School Readiness Year-End Assessment (SReYA) the result is partly upheld by the study. However, It was found out that there is a significant relationship among 2 kindergarten programs and the 3 domains of SReYA such as; fine motor skills and administrator support, numeracy skills and classroom areas, and Sensory-Perceptive and classroom areas. Furthermore, there is a significant difference between the implementation of kindergarten program and curriculum guide, the same result with administrator support. Moreover, there is a significant difference between the implementation of kindergarten program between the big and small schools in terms of administrator support.

\section{Recommendations:-}

Kindergarten teachers, need to develop instructional materials that are localized and can arouse the interest of the pupils. The teachers may collaborate with other schools for instructional materials suited to each lesson. Administrators may have their own SWOT analysis to determine the needs of the young, specifically the kindergarten because this is the crucial phase of learning. Since it is the beginning stage of formal schooling, the analysis drawn by the administrator needs to be considered in the School Improvement Plan (SIP) of the school.

\section{References:-}

1. Blake, M.D. (2008) Foundation of Early Childhood, Second Edition: New Jersey Prentice Hall Inc.

2. Bautista, E.G. (2013). Evaluation of the Implementation of the New Kindergarten Curriculum in the National Capital Region. Philippine Normal University, Manila.

3. Dale E. (1969) Audio-Visual Methods in Teaching. 3rd Ed. New York: Holt, Rinehart \& Winston;p.108.

4. Darling-Hammond, L., \& Bransford, J. (Eds.). (2005). Preparing teachers for a changing world: What teachers should learn and be able to do. San Francisco, CA, US: Jossey-Bass.

5. Dewey, J. (1902) The Child and the Curriculum. Chicago: University of Chicago Press,

6. Gawat, J.S.(2015). Factors Affecting The Level of Readiness in School Readiness Year-End Assessment (SReYA) of Kindergarten Pupils in Cluster 9 Public Elementary Schools of Calamba West District. Laguna State Polytechnic University-Los Banos

7. Guce, J.D. (2012). Attitudes of Grade School and Kindergarten Teachers of Sta.ana Elementary School Towards the New Kindergarten Curriculum. Philippine Normal University, Manila

8. Hamre, BK.,Pianta, R.C., Burchinal, M., Field, S, Crouch, J.L., Downer, J.T.,Howes, C., LaParo, K., Little, C.S. (2012). A course on Effective teacher-child interactions: Effect on teacher beliefs, knowledge, and observed practice. American Educational Research Journal, 49:1, 88-123

9. Hedges, Larry V (2004). How Large Are Teacher Effects? Educational Evaluation and Policy Analysis Fall, Vol.26, No. 3, pp. 237-257

10. Montessori, M. (1964). The montessori method. New York : Schocken Books 
11. Oliver R.M., Wehby J.H., \& Reschy D.J.(2011) Teacher classroom management practices:effects on disruptive or aggressive student behavior. Campbell Systematic Reviews Collaboration

12. Vygotsky, L. S. (1978). Mind in society: The development of higher psychological processes. Cambridge, MA: Harvard University Press.

13. DO. 11 s. 2014- Policy Guidelines on the Implementation of the Kindergarten Catch-Up Education Program

14. DO. 5, s. 2013- Policy Guidelines on the Implementation of the School Readiness Year-End Assessment (SReYA) for Kindergarten

15. DO. 54 s. 2013- Additional Guidelines on the Administration of the School Readiness Year-End Assessment (SReYA)

16. DO 32, s. 2012- Implementing Rules and Regulations of Republic Act (RA) No. 10157 Otherwise Known as "The Kindergarten Education Act"

17. DO 21, s. 2012- Policies and Guidelines of the Implementation of the Universal Kindergarten Education Program

18. DO. 25 s. 2012- Dissemination of Republic Act No. 10157 (An Act Institutionalizing the Kindergarten Education Into the Basic Education System and Appropriating Funds Therefor)

19. R.A. 10157 - Kindergarten Education Act

20. R.A. 10522.- Enhanced Basic Education Act of 2013. 